ББК 63.3.(54)6-454

УДК 94(575)

\title{
Национально-территориальное размежевание в Средней Азии в 1924 г.: причины и влияние на этнополитические процессы в регионе
}

\author{
И.Б. Бочкарева
}

Алтайский государственный университет (Барнаул, Россия)

\section{National-territorial Delimitation in Central Asia in 1924: Causes and Influence on Ethnopolitical Processes in the Region}

\author{
I.B. Bochkareva
}

Altai State University (Barnaul, Russia)

Национальная политика большевиков в 1920-е гг. отличалась высокой степенью конъюнктурности, подчинения ее принципов задачам строительства советской власти. В условиях Гражданской войны и борьбы за власть создание национальных территорий в форме советских автономных республик и районов в составе РСФСР, наряду с поддержкой национальных языков, политических элит и культуры, рассматривалось руководством РКП(б) как действенный политический механизм решения задач укрепления советской власти в национальных районах. Однако провозглашение Туркестанской АССР в мае 1918 г. не привело к нейтрализации национального вопроса в регионе, на что рассчитывали большевики. Политические мотивы укрепления советской власти в Средней Азии в совокупности с низким уровнем национального самосознания и политической активности коренного населения позволили Москве провести новый этап национального размежевания. Национально-территориальное размежевание в Средней Азии в 1924 г. - пример перекодирования процесса национального самоопределения и последующего оформления национального самосознания с тюркского национального проекта, воспринимавшегося как угроза советской власти, на существующие в регионе иные уровни национальной идентичности.

Ключевые слова: большевики, национальное размежевание, Туркестанская АССР, Бухара, Хива, пантюркизм.
The national policy of the Bolsheviks in the 1920s was characterized by a high degree of conjuncture, subordination of its principles to the tasks of Soviet power formation. In the context of the civil war and the struggle for power, the national territories creation in the form of Soviet Autonomous republics and regions within the RSFSR, along with the support of national languages, political elites and culture, was considered by the leadership of the $\mathrm{RCP}(\mathrm{b})$ as an effective political mechanism for solving the problems of strengthening Soviet power in national areas. However, the proclamation of the Turkestan ASSR in May 1918 did not lead to the neutralization of the national issue in the region as the Bolsheviks expected. Political motives for strengthening Soviet power in Central Asia, combined with a low level of national consciousness and political activity of the indigenous population, allowed Moscow to hold a new stage of national division. National-territorial delimitation in Central Asia in 1924 is an example of recoding the process of national self - determination and subsequent registration of national identity from the Turkic national project, perceived as a threat to Soviet power, on existing in the region other levels of national identity.

Key words: Bolsheviks, national delimitation, Turkestan ASSR, Bukhara, Khiva, pan-Turkism.

DOI 10.14258/izvasu(2019)2-03

*Понятие Средняя Азия, сейчас уже историческое, применялось в имперский и советский периоды для обозначения территорий Туркестанского края, Хивы и Бухары, включенных в процесс национального размежевания в 1924 г. Так как термин Средняя Азия нашел отражение в названиях советских органов, в статье мы будем использовать его вместо утвердившегося сейчас названия «Центральная Азия». 
Стратегически национализм воспринимался большевиками как препятствие для складывания пролетарского интернационализма и в перспективе должен был быть изжит. Вместе с тем повсеместный рост местных «национализмов» в национальных регионах России, наблюдавшийся после революции, привел Ленина к выводу, что игнорирование национальных устремлений «угнетенных наций» может, наоборот, привести к их усилению. Национальная политика РКП(б) в начале 1920-х гг. характеризовалась высокой степенью гибкости, конъюнктурности, обусловленной стремлением соотнести свою стратегию строительства социализма с дискурсом по национальному вопросу в конкретном национальном регионе. Туркестанская АССР, провозглашенная в мае 1918 г., стала первой в ряду советских национальных автономий, созданных большевиками в мусульманских регионах России. Однако формальное решение задачи национального самоопределения не привело к нейтрализации национального вопроса в Туркреспублике, как рассчитывали большевики. Именно здесь советская власть столкнулась с мощным сопротивлением со стороны басмаческого движения, боровшегося под лозунгами исламизма и сохранения традиционных устоев местного общества. Не менее серьезным вызовом стали амбиции формирующейся коренной советской элиты Туркреспублики, стремившейся самостоятельно от Москвы решать вопросы национального развития. Политические мотивы укрепления советской власти в Средней Азии привели к новому этапу национального размежевания в 1924 г., фактически определившего современную политическую карту региона. Вместе с тем масштабы территориальных претензий созданных национальных республик друг к другу после национального размежевания, и, главное, рецидив этого явления после распада СССР привели к складыванию в современной историографии стран Центральной азии (ЦА) представления об искусственности, произвольности национальных границ, оценке процесса национального размежевания как нарушившего естественно-историческое развитие народов региона $[1,2]$.

В историографии проблемы высказывается мнение, что большевики в процессе размежевания не ставили себе цели разделить и противопоставить друг другу народы региона, а наоборот, стремились найти критерии унификации населения и объединения его в крупные национальности [3]. А острота территориальных споров, возникших на этапе размежевания, интерпретируется как свидетельство уже имевшихся этнических границах между отдельными тюркскими народами, обусловленных различиями в образе жизни и ведении хозяйства [4].

В статье мы попытаемся проанализировать причины, побудившие большевиков провести нацио- нальное размежевание в Средней Азии, и подходы к осуществлению этого процесса, которых придерживалась центральная власть.

До Февральской революции национальный дискурс в Туркестане находился в зачаточном состоянии. Только после революции туркестанская интеллигенция, представленная джадидами и узкой группой светских русифицированных политиков, начала формулировать свой национальный проект, в основу которого была положена тюркская идентичность. Это было следствием влияния популярных среди тюркоязычных народов Российской империи идей пантюркизма. Вместе с тем обсуждение вопросов национального самоопределения в рамках общероссийского мусульманского движения до Февральской революции показывало, что общетюркское объединение мыслилось как культурный союз, в котором каждый из народов имел бы свою автономию [5, с. 387]. Следовательно, реальное обсуждение национальных проектов шло преимущественно в русле оформления региональных видов национализма, что важно для понимания дальнейшего развития национального вопроса в Средней Азии.

Октябрьская революция прервала процесс национального самоопределения на либерально-демократической основе, однако, как мы отмечали, в апреле 1918 г. была провозглашена Туркестанская автономная советская республика. На наш взгляд, сохранение в системе национальных советских автономий территории под названием «Туркестан» создавало почву для воспроизводства в новых политических условиях местного варианта пантюркизма, и не только противниками советской власти в лице басмаческого движения. Взятый в середине 1918 г. Москвой курс на вовлечение коренного населения в органы советской власти вызвал явление синтеза идей регионального тюркизма и коммунизма. В начале 1920 г. председатель Мусбюро Туркреспублики Турар Рыскулов выдвинул проект переименования республики в Тюркскую советскую республику на основании того, что самоопределяющимся народом является тюркский народ [6, л. 19-20]. При этом Рыскулов допускал возможность расширения границ республики за счет других тюркоязычных народов. Предложения Рыскулова, по сути, представляли собой новую вариацию проекта «Большого Туркестана», тем более, что часть бывших джадидов стала сотрудничать с советской властью, пополнив структуры Мусбюро. Проект Тюркской советской республики свидетельствовал о том, что первое поколение мусульманских коммунистов привлекало в советской альтернативе в первую очередь деколонизационная составляющая и перспектива оформить власть в республике советской по форме и наци- 
ональной по содержанию, если перефразировать высказывание Сталина*.

Уже тогда в противовес коммунистическому пантюркизму в Политбюро ЦК РКП(б) возник план раздела Туркреспублики на три национальные части, в интерпретации Ленина - «на Узбекию, Киргизию и Туркмению» [8, с. 436]. В 1920 г. от этого плана отказались как от преждевременного, но представление Центра о Туркреспублике как многонациональной по типу утвердилось.

В это же время новый центр лоббирования пантюркизма стал формироваться в лице Бухары [9, с. 184]. С провозглашением Бухарской народной советской республики в сентябре 1920 г. пришедшие к власти младобухарцы в своей политике начинают демонстрировать тюркские ориентации как маркеры национальной идентичности и политических симпатий. В качестве образца развития они рассматривали не столько Советскую Россию, сколько Турцию, которая после распада Османской империи сама оформлялась как национальное государство. Младобухарцы взяли курс на сближение с Анкарой, куда была послана делегация для установления дипломатических отношений. В культурно-образовательной сфере произошел перевод делопроизводства с фарси (таджикского) на тюркский язык, всячески поощрялось изучение турецкого языка и литературы $[10$, л. 5]. Стоит отметить и тот факт, что бывший военный министр младотурецкого правительства, сторонник пантюркизма Энвер-паша, направленный Лениным в Бухару осенью 1921 г. с поручением содействовать переходу бухарской мусульманской элиты, включая местных курбаши, на сторону Советов, наоборот, перешел на сторону бывшего бухарского эмира. Энвер-паша возглавил силы басмачей и, позиционируя себя как главнокомандующего армиями ислама, развернул борьбу с советской властью под знаменем панисламизма [11, p. 53-56]. В последующем на сторону Энвера перешли несколько видных деятелей бухарского советского правительства, а также бывший глава ревкома Башкирии А.З. Валидов, но он, в отличие от Энвера, продвигал проект тюркского единства.

Пантюркизм стал восприниматься большевиками в качестве серьезной оппозиционной силы их власти в Туркестане, а соответствующие национальные уклоны в партии классифицировались как «подрывная деятельность». В этой связи размежевание ТуркАССР, а вместе с ней Бухары и Хивы по этническому принци-

^В июне 1918 г. И.В. Сталин в выступлении по вопросам национальной политики РКП(б) в тюркоязычных, мусульманских регионах России отметил: «Автономия есть форма. Весь вопрос в том, какое классовое содержание вкладывается в эту форму. Советская власть $<\ldots>$ за такую автономию, где бы вся власть находилась в руках рабочих и крестьян... Такой автономией и будет автономия на советских началах» [7, л. 32]. пу согласно ленинской схеме рассматривалось руководством ВКП(б), как способ нейтрализации пантюркистских настроений, тем более, что данный подход находил определенную поддержку «снизу».

Действительно, положенный большевиками в основу создания национальных территорий в составе РСФСР этнолингвистический принцип способствовал мобилизации этнического самосознания, которое не являлось определяющим уровнем идентичности населения региона в дореволюционный период. Национальная политика большевиков создала возможности для отдельных групп коренного населения Туркестана путем мобилизации этничности и обоснования особенностей своей культуры и быта улучшить свое социальное положение и статус.

Когда национальное размежевание в Средней Азии вступило в стадию обсуждения местными советскими элитами, каждая национальная группа на почве этнической идентичности боролась за то, чтобы оставаться большинством на выделенной национальной территории, следовательно, иметь более благоприятные условия для доступа к земле, воде, политическому управлению $[12$, c. 105]. Первыми в Туркестанской АССР с инициативой создания отдельных национальных районов в составе республики выступили туркмены в 1921 г., в меньшей степени, чем оседлое население, представленные в советских органах власти. Транскаспийский съезд Советов в начале 1921 г. выдвинул петицию с требованием преобразования Закаспийской области (западной части Туркестана) в «Туркменскую область», которая была удовлетворена [3, p. 232]. Эта инициатива, по сути, положила начало национально-территориальному размежеванию Туркестана по этническому принципу. В 1922 г. с инициативой создания автономного Кара-Киргизского района выступили представители кыргызской интеллигенции, а в 1924 г. в процессе самого размежевания - таджики и каракалпаки [13, с. 28]. Таким образом, параллельно с пантюркизмом и панисламизмом в национальном дискурсе шел процесс оформления местных этнических национализмов. Именно их и поощряли большевики, стремясь изжить пантюркистские настроения части советских элит. Еще одной мотивацией проведения очередного размежевания в регионе было стремление центральной власти интегрировать в советское союзное пространство Бухарскую и Хивинскую народные советские республики, на тот момент формально независимые государства.

К началу 1924 г. советская власть смогла подавить основные очаги басмаческого сопротивления, создать себе социальную опору в регионе, чтобы приступить к новому национально-территориальному «переделу» в Средней Азии. В феврале-марте 1924 г. планы размежевания обсуждались местными партийными органами ТуркАССР, Бухары и Хивы, признавшими, что «вопрос о разделении территории Советской Средней Азии на ряд республик по на- 
циональному признаку вполне назрел и постановка его вполне своевременна» [14, л. 80]. Схема создания на территории Туркреспублики, Бухары и Хорезма Узбекской и Туркменской советских республик с передачей части земель, населенных киргизами (казахами), уже существующей Киргизской АССР, нашла поддержку со стороны местных советских элит.

Центральным в процессе национального размежевания стал проект создания Узбекистана. В случае создания Узбекской республики ярче всего проявились элементы политического конструирования национального строительства со стороны Москвы, поскольку узбекского национального проекта в дискурсе региональной политической элиты до процесса размежевания не существовало. Однако мнение местной партийной элиты относительно границ и идентичности новой национальной единицы тоже учитывалось. С. Абашин отмечает, что узбекский проект стал результатом компромисса между большевиками и местной элитой, джадидами [9, с. 186]. Пантюркизм являлся на тот момент единственным вариантом национализма, консолидирующим национальные элиты Бухары, Хорезма и Туркестана, разделенные политическими границами, но он был неприемлем для большевиков в качестве национальной идеи. Возникавшие в ходе обсуждения предложения создания единого политического объединения в Средней Азии по типу Закавказской федерации также были отклонены Центром по причине их близости пантюркистскому проекту [15, с. 25]. Узбекистан для бывших джадидов представлял собой возможность реализовать проект, близкий к «Тюркской республике», своего рода «Малый Туркестан», что в конечном итоге обеспечило поддержку местной элиты; большевикам же, в свою очередь, было важно решить задачу ухода общетюркских мотивов на второй план [16, с. 208].

Результатом политического компромисса стал выбор узбеков в качестве титульной национальности будущей республики. Согласно итогам переписи населения 1897 г. и данным текущей статистики областных статистических комитетов за 90-е гг. XIX - начала XX в. не меньшую по численности группу коренного населения Туркестана составляли сарты, близкая узбекам по языку и культуре группа [16, с. 150]. Показательно, что в обращении «Ко всем трудящимся мусульманам России и Востока», составленном Лениным, среди народов Туркестана упоминаются только сарты и киргизы [17]. На І съезде Коммунистической партии Туркестана язык сартов был объявлен государственным наряду с русским [13, с. 31]. Однако уже в 1920 г. при подготовке Турккомиссией новой редакции Конституции Туркреспублики узбеки, а не сарты стали позиционироваться, наряду с киргизами и туркменами, в качестве основной народности автономного Туркестана.

Вопрос об этнической природе сартов в их отношении к узбекам еще до революции являлся пред- метом не только академической, но и общественно-политической дискуссии (см. подробнее [16]). Для тюркистски ориентированной джадидской интеллигенции в этом споре более предпочтительным в качестве общего названия являлся этноним «узбек», имеющий, в отличие от «сарт», чисто тюркские корни. Национально-территориальное размежевание 1924 г. вновь актуализировало вопрос о сартах и национальном составе населения будущей Узбекской республики. С позиции упрощения процесса территориального размежевания и последующего управления республикой центральной власти было удобнее объединить близкие по культуре и языку группы населения Средней Азии в одну национальную общность под общим названием. Так как ядром создаваемой Узбекской республики выступала территория Бухары, где самоопределение «сарт», в отличие от Ферганы, не было столь распространено, политический выбор был окончательно сделан в пользу термина «узбек» как определения титульной национальности. Выбор облегчался неопределенностью этнического самосознания местного населения. Официальная перезапись сартов узбеками была проведена во время переписи 1926 г., после которой название «сарт» окончательно было выведено из списка национальностей Советского Союза.

После одобрения ЦК РКП(б) в апреле 1924 г. плана размежевания Средазбюро создало Комиссию по национальному размежеванию для разработки плана делимитации границ новых национальных республик к маю 1924 г. Решая вопросы об отнесении тех или иных территорий Средней Азии к новым национальным республикам, подкомиссии в своей работе должны были опираться на следующие принципы: национальный состав большинства населения рассматриваемой территории; единство территорий новых национальных единиц, чтобы они не были чересполосными. Как ожидалось, создаваемые однородные «национальные республики» должны были снизить градус межэтнических конфликтов и способствовать укреплению советской власти в регионе [18, с. 99].

Однако уже на этапе подготовки проекта делимитации границ разгорелись территориальные споры между местными национальными элитами. В большинстве случаев размежевание рассматривалось ими как возможность расширить территорию своей национальной республики за счет соседей [3, p. 235]. Основным обоснованием территориальных претензий становилась этничность населения той или иной территории, так что речь об общетюркском единстве уже не шла. Так, например, территориальные амбиции казахской стороны распространялись не только на территории Сыр-Дарьинской, Джетысуйской (бывшая Семиреченская) областей Туркреспублики, но и на Аму-Дарьинскую область, Ташкентский 
и Мирзачульский уезды, а также территории тех местностей Ферганы и Памира, где казахи и родственные им группы кара-киргизов, каракалпаков, кипчаков составляют большинство населения [14, л. 37]. Подобные претензии не встретили понимания со стороны других участников процесса.

Советское руководство, начиная со Среднеазиатского бюро и до центральных органов партии, вынуждено было выступать в качестве посредника в этих спорах, искало компромиссные решения на местном уровне. В действительности оно руководствовалось не только национальным принципом (хотя он был приоритетный), но и экономической целесообразностью. Большевики понимали неравнозначность экономических потенциалов и уровня развития создаваемых национальных республик и старались в отдельных случаях нивелировать эту разницу. В основном это происходило путем закрепления за той или иной национальной единицей городских центров, способных выступить полюсом роста для сельской округи. Здесь в качестве примера можно привести передачу Кара-Киргизской АО города Ош в Ферганской долине, где преобладало узбекское население.

11 октября 1924 г. Политбюро ЦК РКП(б) приняло окончательное решение о национальном размежевании в Средней Азии. Узбекская и Туркменская республики, включившиеся в себя территории Бухарской и Хивинской республик, сразу получили статус союзных республик в составе СССР. Киргизская респу- блика пока сохраняла статус автономной для выяснения опыта ее функционирования в новых границах, с возможным последующим преобразованием в союзную [19, л. 23]. Однако национальный вопрос в регионе на этом не решился, в борьбу за национальные территории включились менее крупные по отношению к титульным национальности. Процесс корректировки границ в регионе продолжался до начала 1930-х гг.

Размежевание в Средней Азии в 1924 г. преследовало цель предотвращения роста пантюркистских настроений и возможности реализации на практике проекта Тюркской республики, чего большевики и достигли. В этом случае можно допустить, что национальное размежевание прервало исторически зародившуюся в регионе тенденцию к консолидации сначала политической элиты, а потом населения на основе тюркской идентичности. Признавая наличие элементов конструирования в национальной политике большевиков во время проведении национального размежевания в Средней Азии, следует отметить, что они в то же время улавливали импульсы идущего в регионе процесса оформления этнических национализмов, обусловленного исторически сложившимися различиями в культуре коренного населения. Положив в основу создания национальных территорий и социальной иерархии национальность, большевики ускорили рост этнического самосознания и оформления в перспективе новых вариаций местных национализмов.

\section{Библиографический список}

1. Масов Р. История топорного разделения. Душанбе, 1989.

2. Усубалиев Э. История национально-государственного размежевания Средней Азии [Электронный ресурс]. URL: http://easttime.ru/reganalitic/1/27.html/ (дата обращения: 14.08.2018).

3. Sabol S. The Creation the Soviet Central Asia: the 1924 National Delimitation // Central Asian Survey. 1995. № 14.

4. Казиев С.Ш. Советская национальная политика и проблемы доверия в межэтнических отношениях в Казахстане (1917-1991 годы) : дис. ... д-ра ист. наук. М., 2015.

5. Исхаков С. Российские мусульмане и революция 1917-1918. М., 2004.

6. Российский государственный архив социально-политической истории (РГАСПИ) Ф. 17.ОП. 84. Д. 79.

7. РГАСПИ. Ф. 71. ОП. 34. Д. 1632.

8. Ленин В.И. Замечания на проекте решения ЦК о задачах РКП(б) в Туркестане // Полное собрание сочинений. Т. 41

9. Абашин С. Национализмы в Средней Азии. СПб., 2007.
10. РГАСПИ. Ф. 71. ОП. 34. Д. 1619.

11. Fraser Glenda. Basmachi - I // Central Asian Survey. 1987.

12. Мартин Т. Империя «положительной деятельности». Нации и национализм в СССР, 1923-1929. М., 2011.

13. Койчиев А. Национально-территориальное размежевание в Ферганской долине (1924-1927 гг.) Бишкек, 2001.

14. РГАСПИ. Ф. 62. Оп. 2. Д. 87.

15. Ташенов К.Т. Национально-государственное размежевание в Средней Азии и Казахстане. Алма-Ата, 1960.

16. Абашин С. Этнографическое знание и национальное строительство в Средней Азии («проблема сартов» в XIX - начале XXI в.): дис. ... д-ра ист. наук. М., 2008.

17. Ко всем трудящимся мусульманам России и Востока (Обращение Совета Народных Комиссаров) [Электронный ресурс]. URL: http://constitution.garant.ru/ history/act1600-1918/5310/ (дата обращения: 10. 02. 2018).

18. Халид А. Ислам после коммунизма. Религия и политика в Центральной Азии. М., 2010.

19. РГАСПИ. Ф. 62. ОП. 2. Д. 80. 